\title{
PLURIPOTENT STEM CELLS AND REPROGRAMMING IN HUMAN AND FARM ANIMALS
}

\author{
Jernej OGOREVC ${ }^{1}$, Peter DOVČ ${ }^{2}$
}

Received September 13, 2012; accepted November 20, 2012. Delo je prispelo 13. septembra 2012, sprejeto 20. novembra 2012.

\section{Pluripotent stem cells and reprogramming in human and farm animals}

The importance of pluripotent cells, which can differentiate in to different cell lineages and form an entire organism, is fundamental for understanding developmental biology including emerging diseases and offers potential for numerous applications in medicine and biotechnology. However, molecular mechanisms behind differentiation and de-differentiation (reprogramming) remain largely unknown. Until recently it was possible to obtain stem cells only from embryos in the early stages of development (embryonic stem cells - ESCs) or by using very inefficient and technically difficult method of somatic cell nuclear transfer (SCNT) that requires use of egg cells (oocytes). Both methods raised ethical concerns, especially when using human biological material. On the other hand, induced pluripotent stem cells (iPSCs) can be generated by direct reprogramming of differentiated adult somatic cells. iPSCs show similarities to ESCs and represent ethically acceptable and almost unlimited source of individuum-specific pluripotent cells. iPSCs are particularly important for development of regenerative medicine, disease modelling, drug development and testing, basic research, generation of transgenic animals, and for conservation of endangered species. However, before it is possible to exploit their potential in full, reprogramming processes should be investigated and understood in details and safe methods developed - that will enable production of genetically and epigenetically stable cells without tumorigenic potential. This article provides an overview of the field of iPSCs and addresses some of the latest achievements and applications of pluripotent cells in human and farm animals.

Key words: molecular genetics / reprogramming / iPS cells / pluripotency / stem cells / humans / farm animals

\section{Pluripotentne matične celice in reprogramiranje pri človeku in domačih živalih}

Pomen pluripotentnih celic, ki se lahko diferencirajo v katerokoli celično linijo in omogočajo nastanek celotnega organizma, je bistven za razumevanje razvojne biologije in pojava številnih bolezni ter predstavlja velik aplikativni potencial za medicino in biotehnologijo. Molekularni mehanizmi, pomembni za procese diferenciacije in de-diferenciacije (reprogramiranja), ostajajo v veliki meri nepojasnjeni. Do nedavno je bilo pluripotentne celice mogoče pridobiti le iz embrijev v zgodnjih stopnjah razvoja (embrionalne matične celice - EMC) ali $\mathrm{z}$ uporabo dokaj neučinkovite in tehnično zahtevne metode prenosa jedra somatskih celic (PJSC), ki zahteva uporabo jajčnih celic (oocitov). Obe metodi sprožata številne etične pomisleke, še posebej pri uporabi humanega biološkega materiala. Nasprotno pa lahko inducirane pluripotentne matične celice (iPMC) pridobimo $\mathrm{z}$ direktnim reprogramiranjem diferenciranih odraslih somatskih celic. Po svojih lastnostih so iPMC podobne EMC in predstavljajo etično sprejemljiv in tako rekoč neomejen vir pluripotentnih celic, ki so po svojem genotipu skladne s posameznikovim. iPMC so še posebej pomembne za razvoj regenerativne medicine, modeliranje bolezni, razvoj in testiranje zdravil, bazične raziskave, pripravo transgenskih živali in ohranjanje ogroženih vrst. Preden bo mogoče docela izkoristiti njihov potencial, je potrebno podrobno pojasniti in razumeti procese reprogramiranja in razviti varne metode reprogramiranja, ki bodo omogočale pridobivanje genetsko in epigenetsko stabilnih celic brez tumorigenega potenciala. Članek ponuja širši pregled področja, z nekaterimi najnovejšimi dosežki na področju pridobivanja iPMC in njihovimi možnimi aplikacijami pri človeku in domačih živalih.

Ključne besede: molekularna genetika / reprogramiranje / iPS celice / pluripotentnost / matične celice / človek / domače živali

1 Univ. of Ljubljana, Biotechnical Fac. Dept. of Animal Science, Groblje 3, SI-1230, Slovenia, email: jernej.ogorevc@bf.uni-lj.si

2 same address as 1, e-mail: peter.dovc@bf.uni-lj.si 


\section{INTRODUCTION}

Stem cells are unspecialized cells that can evolve in different cell types during development and growth of an organism. They are also present in adult tissues where they serve as an internal repair system to replace dead or damaged cells. Because they have the capacity to divide indefinitely they can replace cells throughout the entire life cycle of an organism. Stem cells can produce identical cells (symmetric division) or form a pool of stem cells that can be induced to differentiate into any cell of different organs or tissues (asymmetric division). Depending on their differentiation potential stem cells can be classified as toti-, pluri-, multi-, and uni-potent. Pluripotent cells are considered those that can give rise to cells of all three germ layers, but not to the extraembryonic tissues (Do et al., 2006), which is a hallmark of totipotent cells (Mitalipov \& Wolf, 2009). Depending on their source we distinguish two types of stem cells, namely embryonic stem cells (ESCs) and "somatic" stem or progenitor cells that are located in developed tissues and organs. ESCs have capacity to differentiate in all cell types that form an organism (pluripotent character), while progenitor cells represent more differentiated state and can develop only in a few (multipotent) or one (unipotent) cell type of the organ that they reside in.

The existing generic lines of human pluripotent ESCs, first established in 1998 (Thomson et al., 1998), are not genetically matched to individual patients and therefore subjected to immune rejection if used for cell therapy. The long expected ambition of regenerative medicine is the generation of patient-specific pluripotent cells, which can be turned to any desired cell type of the body and then returned to the donor himself (the concept of therapeutic cloning). Until recently, human pluripotent stem cells could be obtained only from early stage embryos, i.e. the ESCs. The procedures that involve embryo destruction or cloning raise ethical concerns which resulted in legal restrictions of embryo manipulation that seriously hampered research (Turnpenny, 2005). But in the year 2006, a huge breakthrough happened - researchers for the first time successfully generated pluripotent stem cells from fully differentiated (somatic) fibroblasts of a mouse using directed dedifferentiation by transduction of transcription factors (Takahashi \& Yamanaka, 2006). Somatic cells that are de-differentiated back to pluripotent state by direct reprogramming are called induced pluripotent stem cells (iPSCs). In the following years, further mouse and human iPSCs were generated that showed similarities to ESCs and corresponded to pluripotency criteria; such as morphological resemblance to ESCs, capability of unlimited self-renewal, expression of specific pluripotency associated surface and endogenous antigens (e.g.
OCT4, SOX2, SSEA-genes, NANOG) capacity of in vitro differentiation to the cells of all three germ layers (endoderm, mesoderm, and ectoderm), and capability of teratoma formation when injected into immunocompromised mouse (Takahashi \& Yamanaka, 2006; Takahashi et al., 2007). Even more stringent criteria of pluripotency can be applied to mouse pluripotent cells that include chimera development with assessment of germline transmission to offspring (Wernig et al., 2007) and tetraploid complementation assay that measures the ability of cells to form an entire organism (Zhao et al., 2009). Latter two of the tests are for obvious ethical/legal reasons not applied as criteria of stemness for human cells.

Although ESCs and iPSCs seem functionally equivalent, a more detailed genetic and epigenetic analysis revealed numerous subtle but substantial differences, which can be probably attributed to technical limitations of current reprogramming methods (Robinton \& Daley, 2012). Therefore, before this ethically uncontroversial and practically unlimited source of pluripotent cells can be used in clinics, it is necessary to explain more about genetic and epigenetic background of reprogramming. Applications of iPSCs are limited with the fidelity of their reprogramming and maintenance of normal genetic and epigenetic state (Pera, 2011).

Farm animals, specifically the domestic pig, represent an excellent model for preclinical research because of the morphological and physiological similarities to human (Kues \& Niemann, 2004). Due to the lack of specific knowledge of in vitro conditions and factors regulating pluripotency for species other than human and rodents, there are no established pluripotent embryonic or germ cell lines available in farm animals. Obviously, iPSCs could become a possible and relative easily obtainable source of pluripotent cells in farm animals, when proper protocols are established. iPSCs from animals would allow animal models to be used in preclinical trials of cell therapy (Nowak-Imialek et al., 2011) and for generation of transgenic animals (technology already well developed in mouse) that could be used for biopharming (e.g. expression of recombinant proteins in milk of livestock species) and agricultural applications.

\section{REPROGRAMMING THE CELLS}

The idea of cell reprogramming is not new, namely the first proof that adult cells can be reprogrammed to a pluripotent state came decades ago by Gourdon et al. (1962). Using technique of somatic cell nuclear transfer (SCNT) they injected frog somatic cell nuclei into enucleated frog oocytes from which feeding tadpoles were successfully developed. Ultimate proof that reprogramming 
is possible also in mammals came in 1996 with cloning of the Dolly. The researchers again used the SCNT method that enabled them to transfer nucleus of mammary epithelial cell into enucleated and treated oocyte leading to a new, cloned animal (Wilmut et al., 1997). Similar experiment was later conducted in mice (Wakayama et al., 1998). This experiments show that under certain stimuli terminally differentiated cells can be reverted back to pluripotent state.

Until recently, it was possible to obtain human stem cells only from the inner cell mass of pre-implantation embryos (ESCs) or, in some species, by using SCNT. SCNT procedure allows generation of individual-specific pluripotent ntES cells (embryonic stem cells by nuclear transfer), but is very inefficient and technically difficult to perform, especially in human. Only recently, the adapted technique of SCNT was successfully used for generation of triploid ntES cells in human (Noggle et al., 2011). Generation of ESCs includes use of embryos, grown in in vitro conditions, in early phases of the development. Therefore, generation of ESCs and ntES cells opened many ethical questions and considerations, especially when manipulating human material and falsely associating therapeutic with reproductive cloning. Additionally, ESCs are not an ideal source of pluripotent cells to be used in personalized medicine because the recipient would need a lifelong treatment with immunosuppressive medications, due to genotype differences.

iPSCs are nowadays technically relatively easy to generate. Additionally, they circumvent ethical considerations, because their generation does not include use of embryos or oocytes, but can be derived directly from different somatic cell types of the individual. For all this reasons iPSCs represent an unlimited source of pluripotent cells that are autologous to the individual and offer great potential for use in personalized medicine (i.e. cell therapy, drug testing, and disease modelling).

\section{METHODS FOR DIRECT REPROGAM- MING}

As already stated, in 2006 the researchers succeeded to derive iPSCs from mouse fibroblasts (Takahashi \& Yamanaka, 2006). Soon after that they derived them also from human fibroblasts (Yu et al., 2007). iPSCs were derived from somatic cells through ectopic expression of defined transcription factors (direct reprogramming), which causes epigenetic changes of the genome and reverts cells back to pluripotent state. Ectopic expression of only a few transcription factors is sufficient to reprogram the cells. Takahashi and Yamanaka (2006) used Oct3/4, Sox2, c-Myc, and Klf4 (Yamanaka factor set - OSKM) to successfully reprogram mouse fibroblasts. Slightly different set of factors was used to reprogram human fibroblasts - OCT4, SOX2, NANOG, and LIN28 (Thomson factor set - OSNL). The reprogramming cocktail (combination of factors) is much dependent on the donor cell type and cell culture conditions. For example, neural stem cells were successfully reprogrammed to pluripotency by ectopic expression of only OCT4 transcription factor (Kim et al., 2009).

In recent years different methods, using different combinations of factors and different approaches for their delivery into cells, have evolved. In general, reprogramming methods can be divided to those which alter genome of the cells (viral transduction, transfection) and non-integrating methods, which reprogram cells without genome interventions (episomal transient transfection or use of transgene-free methods).

First iPSCs were generated using lentiviruses or

Table 2: Overview of the methods for iPSCs generation

Preglednica 2: Pregled metod za ustvarjanje iPMC

\begin{tabular}{|c|c|c|c|}
\hline & Method & Pros & Cons \\
\hline \multirow{3}{*}{ 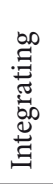 } & $\begin{array}{l}\text { Retroviruses, } \\
\text { Lentiviruses }\end{array}$ & effective and reproducible & genome integration \\
\hline & Linear DNA & vector free & possibility of genomic integration, average efficiency \\
\hline & PiggyBac transposons & deletion of vector possible & slow, average efficiency, possibility of genomic integration \\
\hline \multirow{5}{*}{ 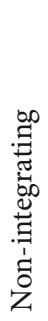 } & Adenoviruses & no genome integration & slow and inefficient \\
\hline & Episomal plasmids & no genome integration & $\begin{array}{l}\text { dilution of gene doses - inefficient, possibility of genomic } \\
\text { integration }\end{array}$ \\
\hline & Proteins and small molecules & transgene-free & inefficient, slow \\
\hline & mRNA & transgene-free, efficient & $\begin{array}{l}\text { high gene doses of oncogenes, multiple transfections re- } \\
\text { quired }\end{array}$ \\
\hline & miRNA & transgene-free & usually successful only in combination with other methods \\
\hline
\end{tabular}


retroviruses to deliver factors into the cells. Viral integration methods still represent golden standard for efficiency and reproductivity in cell reprogramming. However, using viral integrating methods results in expression of potentially harmful oncogenic factors delivered to cells (e.g. MYC). Additionally, random viral integration generates heterogenic iPSC lines that carry randomly distributed transgene insertions, which can disrupt functions of tumor suppressor genes (if inserted in open reading frames) or alter expression of oncogenes. Moreover, viral transgenes should be silenced after successful reprogramming and endogenous factors reactivated, but a question of proper transgene silencing and possibility of transgene reactivation during life of iPSCs exists (for a more detailed review about advantages and disadvantages of reprogramming methods see Gonzalez et al., 2011). Therefore, safer methods that allow deletion of inserted transgenes or do not include genome interventions at all were developed in recent years. iPSCs have been obtained by using piggyback transposons (Woltjen et al., 2009), episomes (Yu et al., 2009), proteins (Kim et al., 2009), synthetic mRNA (Warren et al., 2010), and miRNA (Miyoshi et al., 2011). An overview of known reprogramming methods, with their advantages and disadvantages, is presented in Table 1.

\section{INDUCED PLURIPOTENT STEM CELLS IN FARM ANIMALS}

ESCs and iPSCs from farm animals are expected to become a perfect source of cells for genome editing, because of their indefinite proliferation in vitro, and more importantly, because they can form any cell type of the body or the whole organism. This technology could enable the production or health traits to be improved in farm animals, by manipulating their genetic composition. However, no validated germline competent ESCs have been developed in livestock to date. On the other hand, direct cell reprogramming enabled the generation of pluripotent stem cells from adult cells in several species, but the lack of established ESC lines, which would serve as a gold standard of pluripotent cells (as are the generic ESC lines in human and mouse), makes the assessment and comparison of pluripotency in farm animals difficult.

Beside efficient reprogramming in primates and murine iPSCs production was extended to agriculturally important species including pig, cow, and sheep (Malaver-Ortega, 2012). Porcine iPSCs (piPSCs) were successfully derived from fetal fibroblasts by using retroviral transduction of human or mouse OSKM factors (Esteban et al., 2009). Additionally, piPSCs were success- fully derived from ear fibroblast, bone marrow (Wu et al., 2009), and mesenchymal stem cells, which were capable of generating chimeric offspring (West et al., 2010).

Generation of bovine (Sumer et al., 2011) and sheep (Liu et al., 2012) iPSCs (biPSCs and siPSCs) was recently reported using human orthologs of OSKM factors delivered to bovine fibroblasts using retroviruses. Reprogrammed biPSCs resulted in generation of putative iPSC colonies, which were unstable beyond early passages. After addition of NANOG to the reprogramming cocktail, long term biPSCs were obtained (Sumer et al., 2011). Recently, generation of biPSC-like cells from bovine fibroblasts was reported using non-integrating virus-free vector, containing bovine OSKM transcription factors under conditions of chemically defined signal inhibition of several protein kinases (Huang et al., 2011). Although the biPSC-like cells formed colonies and expressed pluripotency-typical markers, the colonies did not expand after passage. It seems that in bovine speciesspecific requirements exist that include NANOG as the transcription factor necessary for complete reprogramming (Malaver-Ortega et al., 2012).

Little is known about pluripotent stem cells in goats, although they are great model organisms and important for production of human recombinant proteins (NowakImialek et al., 2011). Goat ESCs have been isolated from blastocyst but have lost characteristics of pluripotent cells only after few passages (Pawar et al., 2009). Recently, goat iPSCs were obtained from goat fibroblasts by using lentiviral vectors, which contained human OCT3/4, SOX2, cMYC, KLF4, hTERT, and SV40 antigen (Ren et al., 2011).

Equine iPSCs (eiPSCs) were also generated using retroviral vector containing murine OSKM factors (Breton et al., 2012) or piggyBack transposons (which allows excision of inserted transgenes after reprogramming) as a transgene delivery for murine OSKM combined with tetracycline inducible system (Nagy et al., 2011).

The experiments in farm animals show that similar methods of reprogramming can be successfully used in human, murine and farm animals indicating universality of reprogramming processes across species. The experiments also showed that human or murine transcription factors were sufficient to reprogram cells of several livestock species, which further points to high conservation of pluripotency genes between species. However, possible species-specific requirements may exist to achieve bona fide iPS cells. 


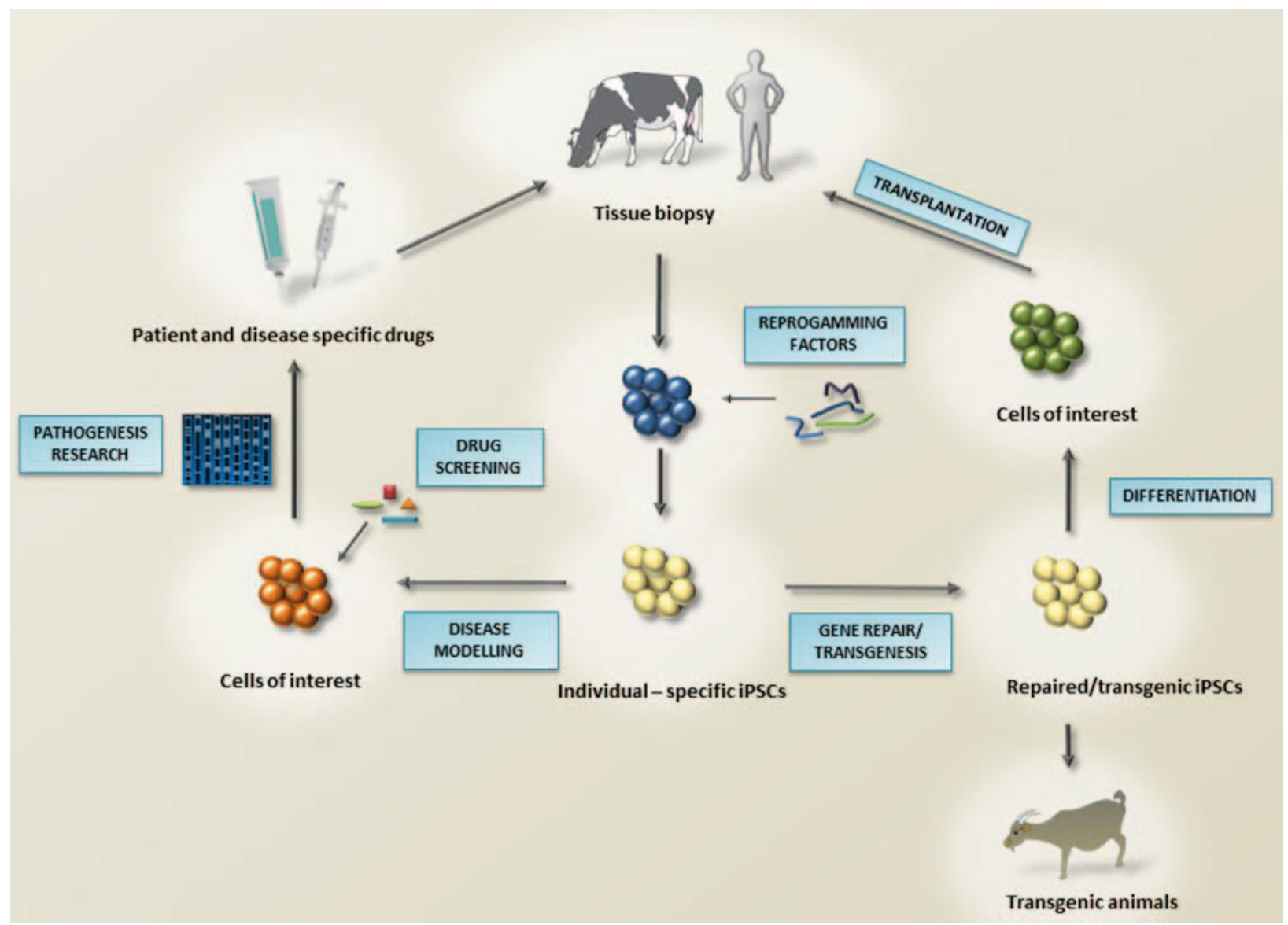

Figure 1: Applications of iPSCs (some of the symbols used on the figure were taken from IAN symbol libraries (http://ian.umces.edu/symbols/) Slika 1: Aplikacije iPMC (nekateri simboli, uporabljeni na sliki, so bili pridobljeni iz zbirke simbolov IAN (http://ian.umces.edu/symbols/)

\section{APPLICATIONS OF IPSCS AND FUTURE CHALLENGES}

Reprogramming somatic cells to pluripotent state is one of the most important research topics in modern science, because iPSCSs offer great potential for use in basic research, biotechnology, agriculture, pharmacy, and medicine. In the species in which the embryonic stem cells are hard to isolate and maintain, iPSCs could be used for generation of transgenic animals with special production characteristics or resistance against diseases. For example, transgenic goats are often used for biopharming human recombinant proteins. The first marketed human recombinant protein - anthithrombin III has been expressed and isolated from mammary glands of transgenic goats (Niemann \& Kues, 2003). The reprogramming technology could also be applied to revive endangered or extinct species (Ben-Nun et al., 2011).

In human medicine, iPS cells hold a great potential for development of personalized medicine. The cells can be used for in vitro drug screening to evaluate therapeutic effects and toxicity of a drug on the affected cells of an individual patient. Similarly, iPSCs generated from patient's affected cells and differentiated to any particular cell type of the body enable disease specific physiological mechanisms, attributed to genetic variations (e.g. particular mutations), to be studied in a culture dish. Such effective disease modelling allows generation of in vitro models for different forms of the disease, including individuals with sporadic or multifactorial diseases of unknown genetic causes. iPSCs based disease models can be used to identify and test new drugs to treat diseases. Ultimate goal of iPSCs technology in medicine is to generate properly reprogrammed and safe pluripotent cells for cell replacement therapy in combination with gene targeting and correction technologies that allow tailoring (repairing) of the genome (e.g. zinc finger nucleases technology, homologous recombination). (Chun et al., 2010; Okita \& Yamanaka, 2011; Robinton \& Daley, 2012). For the proof of a principle, such experiment was already demonstrated in the mouse sickle cell anemia model. The wild type $\beta$-globin gene was successfully used to replace the mutated gene by homologous recombination of iPSCs, which were then differentiated to hematopoietic progenitors 
and transplanted back to the mouse that restored a normal physiological function (Hanna et al., 2007). Possible applications of iPSCs are presented in Fig. 1.

Variations in fidelity of epigenetic reprogramming can be quite significant even in iPSCs that otherwise meet established pluripotency criteria. Remainings of the donor cell type-specific epigenetic patterns ("somatic memory" of the cells) and other unknown factors can affect differentiation potential of iPSCs, which can significantly differ from ESCs. Characterization of iPSCs usually involves functional tests, which begin with in vitro differentiation. Cells are usually differentiated to embryoid bodies and different cell types of all three germ lineages. Golden standard to prove the pluripotency in human is formation of tumors (teratomas) after injection of iPSCs intramuscularly or subcutaneously into immunodeficient mice (Robinton \& Daley, 2012). Before iPSCs could be used in regenerative medicine, it is necessary to assess fidelity of their reprogramming, survival potential, capability of functional integration into the tissue, genetic stability, and absence of tumorigenic potential that is often associated with reprogramming. For this purposes, animal models should be developed and used in preclinical trials (Nowak-Imialek et al., 2011).

The best strategy for future iPSCs derivation would be the reduction in number of transcription factors used, especially potential oncogenes, and the use of methods that are not based on integration of exogenous DNA into the genome (Zhao et al., 2009). Integration-free methods can be improved by better combinations of factors, selection of an easily reprogrammable parental cell type, and by determining optimal culture conditions (Okita \& Yamanaka, 2011). As an alternative to iPSCs, it is also possible to induce somatic cells directly into other somatic cell types in a process called transdifferentiation or lineage reprogamming. Transdifferentiated cells would bypass pluripotent state and presumably be less tumorigenic, however, direct transitions between distantly related cell types are yet to be determined (for review see Vierbuchen \& Wernig, 2011).

\section{REFERENCES}

Ben-Nun I.F., Montague S.C., Houck M.L., Tran H.T., Garitaonandia I., Leonardo T.R., Wang Y.C., Charter S.J., Laurent L.C., Ryder O.A., Loring J.F. 2012. Induced pluripotent stem cells from highly endangered species. Nat Methods, 8: 829-31

Breton A., Sharma R., Diaz A.C., Parham A.G., Graham A., Neil C., Whitelaw C.B., Milne E. \& Donadeu F.X. 2012. Derivation and Characterization of Induced Pluripotent Stem Cells from Equine Fibroblasts. Stem Cells Dev [e-version, ahead of print].
Chun Y.S., Chaudhari P., Jang Y.Y. 2010. Applications of patientspecific induced pluripotent stem cells; focused on disease modeling, drug screening and therapeutic potentials for liver disease. Int J Biol Sci, 6: 796-805

Do J.T., Han D.W., Scholer H.R. 2006. Reprogramming somatic gene activity by fusion with pluripotent cells. Stem Cell Rev, 2: 257-64

Esteban M.A., Xu J., Yang J., Peng M., Qin D., Li W., Jiang Z., Chen J., Deng K., Zhong M., Cai J., Lai L., Pei D. 2009. Generation of induced pluripotent stem cell lines from Tibetan miniature pig. J Biol Chem, 284: 17634-40

Gonzalez F., Boue S., Izpisua Belmonte J.C. 2011. Methods for making induced pluripotent stem cells: reprogramming a la carte. Nat Rev Genet, 12: 231-42

Gurdon J.B. 1962. Adult frogs derived from the nuclei of single somatic cells. Dev Biol, 4: 256-73

Hanna J., Wernig M., Markoulaki S., Sun C.W., Meissner A., Cassady J.P., Beard C., Brambrink T., Wu L.C., Townes T.M., Jaenisch R. 2007. Treatment of sickle cell anemia mouse model with iPS cells generated from autologous skin. Science, 318: 1920-3

Huang B., Li T., Alonso-Gonzalez L., Gorre R., Keatley S., Green A., Turner P., Kallingappa P.K., Verma V., Oback B. 2011. A virus-free poly-promoter vector induces pluripotency in quiescent bovine cells under chemically defined conditions of dual kinase inhibition. PLoS One, 6: e24501

Kim D., Kim C.H., Moon J.I., Chung Y.G., Chang M.Y., Han B.S., Ko S., Yang E., Cha K.Y., Lanza R., Kim K.S. 2009a. Generation of human induced pluripotent stem cells by direct delivery of reprogramming proteins. Cell Stem Cell, 4 : 472-6

Kim J.B., Greber B., Arauzo-Bravo M.J., Meyer J., Park K.I., Zaehres H., Scholer H.R. 2009b. Direct reprogramming of human neural stem cells by OCT4. Nature, 461: 649-3

Kues W.A., Niemann H. 2004. The contribution of farm animals to human health. Trends Biotechnol, 22: 286-94

Liu J., Balehosur D., Murray B., Kelly J.M., Sumer H., Verma P.J. 2012. Generation and characterization of reprogrammed sheep induced pluripotent stem cells. Theriogenology, 77: $338-46$ el

Malaver-Ortega L.F., Sumer H., Liu J., Verma P.J. 2012. The state of the art for pluripotent stem cells derivation in domestic ungulates. Theriogenology, 78, 8: 1749-62

Mitalipov S., Wolf D. 2009. Totipotency, pluripotency and nuclear reprogramming. Adv Biochem Eng Biotechnol, 114: 185-99

Miyoshi N., Ishii H., Nagano H., Haraguchi N., Dewi D.L., Kano Y., Nishikawa S., Tanemura M., Mimori K., Tanaka F., Saito T., Nishimura J., Takemasa I., Mizushima T., Ikeda M., Yamamoto H., Sekimoto M., Doki Y., Mori M. 2011. Reprogramming of mouse and human cells to pluripotency using mature microRNAs. Cell Stem Cell, 8: 633-8

Nagy K., Sung H.K., Zhang P.Z., Laflamme S., Vincent P., AghaMohammadi S., Woltjen K., Monetti C., Michael I.P., Smith L.C., Nagy A. 2011. Induced Pluripotent Stem Cell Lines Derived from Equine Fibroblasts. Stem Cell Reviews and Reports, 7: 693-702 (Erratum: 8, 2012: 546)

Niemann H., Kues W.A. 2003. Application of transgenesis in 
livestock for agriculture and biomedicine. Anim Reprod Sci, 79: 291-317

Noggle S., Fung H.L., Gore A., Martinez H., Satriani K.C., Prosser R., Oum K., Paull D., Druckenmiller S., Freeby M., Greenberg E., Zhang K., Goland R., Sauer M.V., Leibel R.L., Egli D. 2011. Human oocytes reprogram somatic cells to a pluripotent state. Nature, 478: 70-U81

Nowak-Imialek M., Kues W., Carnwath J.W., Niemann H. 2011. Pluripotent stem cells and reprogrammed cells in farm animals. Microsc Microanal, 17: 474-97

Okita K., Yamanaka S. 2011. Induced pluripotent stem cells: opportunities and challenges. Philosophical Transactions of the Royal Society B-Biological Sciences, 366: 2198-207

Pawar S.S., Malakar D., De A.K., Akshey Y.S. 2009. Stem celllike outgrowths from in vitro fertilized goat blastocysts. Indian J Exp Biol, 47: 635-42

Pera M.F. 2011. STEM CELLS: The dark side of induced pluripotency. Nature, 471: 46-7

Ren J., Pak Y., He L., Qian L., Gu Y., Li H., Rao L., Liao J., Cui C., Xu X., Zhou J., Ri H., Xiao L. 2011. Generation of hircineinduced pluripotent stem cells by somatic cell reprogramming. Cell Res, 21: 849-53

Robinton D.A., Daley G.Q. 2012. The promise of induced pluripotent stem cells in research and therapy. Nature, 481: 295-305

Sumer H., Liu J., Malaver-Ortega L.F., Lim M.L., Khodadadi K., Verma P.J. 2011. NANOG is a key factor for induction of pluripotency in bovine adult fibroblasts. J Anim Sci, 89: 2708-16

Takahashi K., Tanabe K., Ohnuki M., Narita M., Ichisaka T., Tomoda K., Yamanaka S. 2007. Induction of pluripotent stem cells from adult human fibroblasts by defined factors. Cell, 131: 861-72

Takahashi K., Yamanaka S. 2006. Induction of pluripotent stem cells from mouse embryonic and adult fibroblast cultures by defined factors. Cell, 126: 663-76

Thomson J.A., Itskovitz-Eldor J., Shapiro S.S., Waknitz M.A., Swiergiel J.J., Marshall V.S., Jones J.M. 1998. Embryonic stem cell lines derived from human blastocysts. Science, 282: 1145-7

Turnpenny L. 2005. Embryo's moral status is unaffected by alteration. Nature, 437: 26

Vierbuchen T., Wernig M. 2011. Direct lineage conversions: unnatural but useful? Nat Biotechnol, 29: 892-907
Wakayama T., Perry A.C.F., Zuccotti M., Johnson K.R., Yanagimachi R. 1998. Full-term development of mice from enucleated oocytes injected with cumulus cell nuclei. Nature, 394: 369-74

Warren L., Manos P.D., Ahfeldt T., Loh Y.H., Li H., Lau F., Ebina W., Mandal P.K., Smith Z.D., Meissner A., Daley G.Q., Brack A.S., Collins J.J., Cowan C., Schlaeger T.M., Rossi D.J. 2010. Highly efficient reprogramming to pluripotency and directed differentiation of human cells with synthetic modified mRNA. Cell Stem Cell, 7: 618-30

Wernig M., Meissner A., Foreman R., Brambrink T., Ku M., Hochedlinger K., Bernstein B.E., Jaenisch R. 2007. In vitro reprogramming of fibroblasts into a pluripotent ES-cell-like state. Nature, 448: 318-24

West F.D., Terlouw S.L., Kwon D.J., Mumaw J.L., Dhara S.K., Hasneen K., Dobrinsky J.R., Stice S.L. 2010. Porcine induced pluripotent stem cells produce chimeric offspring. Stem Cells Dev, 19: 1211-20

Wilmut I., Schnieke A.E., McWhir J., Kind A.J., Campbell K.H. 1997. Viable offspring derived from fetal and adult mammalian cells. Nature, 385: 810-3

Woltjen K., Michael I.P., Mohseni P., Desai R., Mileikovsky M., Hamalainen R., Cowling R., Wang W., Liu P., Gertsenstein M., Kaji K., Sung H.K., Nagy A. 2009. piggyBac transposition reprograms fibroblasts to induced pluripotent stem cells. Nature, 458: 766-70

Wu Z., Chen J., Ren J., Bao L., Liao J., Cui C., Rao L., Li H., Gu Y., Dai H., Zhu H., Teng X., Cheng L., Xiao L. 2009. Generation of pig induced pluripotent stem cells with a druginducible system. J Mol Cell Biol, 1: 46-54

Yu J., Hu K., Smuga-Otto K., Tian S., Stewart R., Slukvin, II, Thomson J.A. 2009. Human induced pluripotent stem cells free of vector and transgene sequences. Science, 324: 797801

Yu J., Vodyanik M.A., Smuga-Otto K., Antosiewicz-Bourget J., Frane J.L., Tian S., Nie J., Jonsdottir G.A., Ruotti V., Stewart R., Slukvin I.I., Thomson J.A. 2007. Induced pluripotent stem cell lines derived from human somatic cells. Science, 318: 1917-20

Zhao X.Y., Li W., Lv Z., Liu L., Tong M., Hai T., Hao J., Guo C.L., Ma Q.W., Wang L., Zeng F., Zhou Q. 2009. iPS cells produce viable mice through tetraploid complementation. Nature, 461: 86-90 